\title{
IMPLEMENTASI NILAI DAN ETIKA DALAM MENINGKATKAN MUTU DI SEKOLAH DASAR MUHAMMADIYAH SAMBISARI
}

\author{
Sholawati \\ Universitas Muhammadiyah Yogyakarta \\ sholawati.psc19@mail.umy.ac.id
}

\begin{abstract}
ABSTRAK
Penelitian ini bertujuan untuk mendeskripsikan bagaimana penerapan nilai dan etika dalam meningkatkan mutu di SD Muhammadiyah Sambisari Sleman. Penelitian ini merupakan jenis penelitian yang menggunakan pendekatan deskriptif kualitatif. Pengumpulan data dilakukan dengan studi pustaka, observasi dan wawancara dengan kepala sekolah SD Muhammadiyah Sambisari sebagai manajer instansi. Data yang sudah terkumpul kemudian direduksi dan ditarik kesimpulan. Hasil penelitian menunjukkan bahwa nilai dan etika yang diimplementasikan dalam instansi pendidikan dapat menunjang peningkatan mutu. Dalam meningkatkan mutu, SD Muhammadiyah Sambisari membangun kepercayaan (trust), integritas, dan tanggung jawab secara konsisten. Nilai-nilai ini dicontohkan oleh kepala sekolah sebagai leader dan dianut oleh seluruh anggota instansi, terutama guru, karyawan, dan siswa. Sekolah yang memiliki sarana dan prasarana atau fasilitias yang minimal pun dapat membangun budaya mutu dan terus meningkatkan kualitasnya. Hal ini menunjukkan penerapan nilai dan etika menjadi faktor yang sangat penting dalam upaya peningkatan mutu.
\end{abstract}

Kata kunci: nilai, etika, manajemen mutu pendidikan

\begin{abstract}
This research aims to describe how the implementation of values and ethic to improving the quality at Muhammadiyah Elementary School. It is a type of study that employs a qualitative descriptive approach. Data collection was done with a library study, observation and interview with Sambisari elementary school principal as an institution manager. The collected data is then reduced and drawn to conclusions. Studies indicate that values and ethics implemented in the institution of education can promote improvements. In improvements, sambisari muhammadiyah elementary school builds trust (trust), integrity and responsibility consistently. These values are exemplified by the principal as a leader and are adopted by all members of the agency, especially teachers, employees, and students. Even schools with minimal means and infrastructure or facilities can build a culture of quality and continue to enhance it. This suggests the application of values and ethics to be a crucial factor in improvement.
\end{abstract}

Key words: value, ethics, total quality management in education 


\section{PENDAHULUAN}

Manajemen mutu terpadu berawal dari perjalanan industri Jepang yang mengalami kehancuran total akibat Perang Dunia II. Untuk membangun kembali dan bangkit dari kehancuran industri di negaranya, pada tahun 1950 Asosiasi Insinyur Jepang mengundang William Edward Deming yang dikenal sebagai Bapak Mutu untuk melatih para insinyur Jepang dalam bidang manajemen untuk mencapai mutu, yang kemudian dikenal dengan istilah Total Quality Management (Hairiyah, 2015).

Di Indonesia Total Quality Management (TQM) dikenal dengan istilah Manajemen Mutu Terpadu (MMT). Selain dalam dunia industri atau bisnis, manajemen mutu juga diterapkan dalam dunia pendidikan. MMT dalam lembaga pendidikan merupakan suatu pendekatan yang sistematis, praktis, dan strategis bagi penyelenggaraan pendidikan yang mengutamakan kepuasan pelanggan yang bertujuan meningkatkan mutu (Peter dalam Sallis, 2002). Pengertian tersebut tidak menekankan satu komponen dalam sistem pendidikan, tetapi menyangkut seluruh komponen penyelenggaraan pendidikan yaitu input, proses, dan output serta semua perangkat yang mendukungnya.

Aspek mutu akan memberi manfaat bagi dunia pendidikan setidaknya karena peningkatan mutu merupakan tanggung jawab lembaga pendidikan untuk memberikan layanan pada peserta didik. Peningkatan kualitas atau mutu pendidikan merupakan suatu proses yang terintegrasi dengan proses peningkatan kualitas sumber daya manusia itu sendiri. Mc Laughlin menyebutkan bahwa manajemen mutu tidak sekedar suatu pendekatan atau strategi, tetapi lebih merupakan sistem atau suatu cara (the way of life) untuk mencapai tujuan secara efisien agar dapat memenuhi tuntutan pengguna melalui penyempurnaan yang di lakukan secara terus menerus (Sukmadinata et al., 2008). Untuk mewujudkan suatu pendidikan yang bermutu dan berdaya saing tinggi, maka lembaga pendidikan (sekolah, pesantren, dan madrasah) harus menerapkan suatu konsep yang berorientasikan pada mutu. Pendekatan menejerial berbasis Total Quality Manajemen (TQM) menjadi sebuah keniscayaan yang harus dilakukan oleh lembaga pendidikan untuk meningkatkan kualitas (Priatna, 2018).

Mutu sesuai yang disyaratkan atau distandarkan (conformance to requirement), yaitu sesuai dengan standar mutu yang telah ditentukan, baik inputnya, prosesnya maupun outputnya. Oleh karena itu, mutu pendidikan yang diselenggarakan sekolah dituntut untuk memiliki standar baku mutu pendidikan. Mutu dalam konsep Deming adalah kesesuaian dengan kebutuhan pasar. Dalam konsep Deming, pendidikan yang bermutu adalah pendidikan yang dapat menghasilkan keluaran, baik pelayanan dan lulusan yang sesuai kebutuhan atau harapan pelanggan/pasarnya. Sedangkan Fiegenbaum mengartikan mutu adalah kepuasan pelanggan sepenuhnya (full customer satisfaction). Dalam pengertian ini, maka yang dikatakan sekolah bermutu adalah sekolah yang dapat memuaskan pelanggannya, baik pelanggan internal maupun eksternal (Crosby, 1979).

Lembaga pendidikan sebagai sarana dalam menciptakan generasi bangsa yang mampu menjual kualitas dan keunggulan kehidupan bangsa kedepannya diharapkan mampu melahirkan lulusan yang bermutu (Gustini \& Mauly, 2019). Pendidikan yang berkualitas merupakan salah satu faktor kepuasan siswa dan orang tua sebagai stakeholder atau pelanggan dalam 
pendidikan. Dalam hal kepuasan pelanggan, maka yang bertanggung jawab penuh adalah pihak yang menjalankan pendidikan. Dalam hal ini kepala sekolah sebagai pemimpin atau leader, dan guru serta karyawan sebagai anggota organisasi atau instansi. Sekolah yang memiliki kualitas mutu yang baik, biasanya menjadi pilihan bagi orang tua untuk menyekolahkan anak-anak mereka. Sehingga sekolah memiliki jumlah siswa yang maksimal. Ditunjang dengan sarana dan prasarana yang lengkap sesuai standar, staf pengajar yang professional, serta sumber belajar yang memadai. Terutama anggapan paling umum tentang sekolah yang bermutu adalah lengkapnya fasilitas dan layanan yang disediakan oleh sekolah. Fasilitas merupakan faktor utama dalam hal kepuasan siswa (Sapri et al., 2009).

Namun, dengan indikator yang demikian ideal, tidak semua sekolah mampu mencapai kualitas terbaik. Sehingga perlu adanya manajemen mutu untuk memaksimalkan semua komponen sekolah. Pentingnya manajemen mutu di lembaga pendidikan atau sekolah telah banyak dibahas. Misalnya oleh Saparina et al (2020) mengenai manajemen mutu dalam meningkatkan layanan sekolah di SD Muhammadiyah 7 Bandung, dimana secara umum sekolah masih didominasi peringkat B dalam penilaian Badan Akreditasi Nasional, sehingga peningkatan mutu dan kualitas harus terus dilakukan. Terutama dalam hal layanan yang diberikan sekolah kepada siswa dan orang tua harus terus menerus ditingkatkan.

Banyaknya sekolah yang memiliki keterbatasan dalam sarana dan prasarana, tenaga pengajar yang professional, serta berbagai hal lain yang memang belum tersedia di sekolah, seharusnya tidak mengurangi semangat para pengelola instansi pendidikan tersebut untuk terus meningkatkan mutu. Salah satunya seperti di SD Muhammadiyah Sambisari. SD Muhammadiyah Sambisari adalah sebuah pendidikan dasar di Kabupaten Sleman, provinsi DIY. Berdiri di lahan seluas 800 meter persegi, sekolah ini sangat terbatas dalam hal sarana dan prasarana. Ruang kelasnya sempit, ruang perpustakaan tidak memadai, tidak memiliki lapangan olahraga sendiri. Diantara staf pengajar hanya ada satu orang guru yang memiliki sertifikat pendidik. Kepala sekolah sebagai manajer atau leader mengusahakan perbaikan mutu terus menerus untuk mencapai tujuan yang diharapkan.

Salah satu cara yang dilakukan oleh kepala SD Muhammadiyah Sambisari meningkatkan mutu adalah dengan menerapkan nilai dan etika secara intens. Sebab instansi pendidikan yang menerapkan pendekatan MMT tidak akan dapat terwujud dengan baik, manakala di institusi tersebut para karyawannya dalam berperilaku tidak memegang etika. Perilaku beretika dalam MMT sangat penting. Nilai dan etika dianggap sangat penting karena keberhasilan manajemen mutu total tergantung pada delapan komponennya, dan yang paling utama adalah etika (Hadi, 2018).

Setiap individu dalam sebuah organisasi harus memiliki nilai-nilai yang dipegang teguh dan diamalkannya. Nilai adalah sesuatu yang diyakini secara mendalam yang membentuk ciri atau warna siapakah seseorang itu (Goetsch \& Davis, 1994). Nilai-nilai yang dianut oleh seseorang akan membimbing perilakunya, begitu juga dengan sebuah organisasi. Sebuah organisasi tidak akan menghasilkan barang/jasa yang bermutu jika organisasi tersebut tidak memegang nilai-nilai bahwa peduli mutu merupakan hal yang menjadi ciri utama 
organisasi tersebut. Pengetahuan dan keterampilan karyawan adalah penting, tetapi tidak menjamin dihasilkannnya produk/jasa yang bermutu. Hal tersebut karena karyawan dan organisasi secara keseluruhan akan menerapkan pengetahuan dan keterampilannya sesuai dengan nilai yang mereka yakini dan mereka rasakan bahwa itu adalah penting.

Sebuah penelitian menyebutkan bahwa dalam bisnis berlaku prinsipprinsip etika yang harus dipatuhi pelaku bisnis. Prinsip tersebut antara lain adalah prinsip otonomi yaitu pengambilan keputusan dan tindakan atas dasar tanggung jawab moral, prinsip kejujuran, prinsip keadilan, prinsip saling menguntungkan dan prinsip integritas moral merupakan prinsip dasar dalam menjalankan usaha atau organisasi (Ali, 2020). Selain itu, penelitian lain membahas 14 nilai etika dalam kesuksesan bisnis. Nilai etika tersebut adalah kejujuran, integritas, tanggung jawab, kualitas, kepercayaan, respek, kerja tim, kepemimpinan yang baik, etika sosial, fokus pelayanan, serta kepuasan karyawan (Singh \& Singh, 2012). Dalam rangka mensukseskan bisnis dalam persaingan yang semakin ketat maka semua nilai-nilai ini harus diterapkan di dalam perusahaan/organisasi untuk meciptakan sebuah lingkungan kerja yang kondusif dan mendukung tercapainya kesuksesan dalam bisnis. Demikian pula dalam instansi pendidikan perlu adanya nilai dan etika yang dianut oleh semua stakeholder.

Kajian mengenai nilai dan etika dalam meningkatkan mutu masih sangat sedikit, terutama dalam pendidikan, sehingga perlu dilakukan penelitian ini. Artikel ini akan membahas bagaimana nilai-nilai dan etika yang diterapkan oleh lembaga pendidikan. Dimana dalam dunia pendidikan juga mengadopsi nilai dan etika yang sama dengan organisasi atau perusahaan. Studi kasus dilakukan di SD Muhammadiyah Sambisari Kabupaten Sleman.

\section{METODE}

Penelitian ini menggunakan metode deskriptif kualitatif. Yaitu dengan teknik menggambarkan dan menjelaskan data-data yang telah dikumpulkan dengan cara memperhatikan dan merekam sebanyak mungkin aspek yang diteliti sehingga mendapatkan gambaran secara menyeluruh tentang kondisi yang sebenarnya (Creswell, 2014). Langkah-langkah analisis data pada penelitian ini adalah pengumpulan data (data collection), pereduksian data (data reduction), penyajian data (data display), dan menarik kesimpulan (conclusion drawing/verification). Pengumpulan data dilakukan dengan studi pustaka, yaitu membaca literatur yang berhubungan dengan Manajemen Mutu Terpadu, baik dari buku-buku maupun jurnal yang terbit secara online. Selain itu observasi dan wawancara dilakukan di lingkungan SD Muhammadiyah Sambisari, terutama wawancara dengan kepala sekolah selaku leader atau manajer di satuan pendidikan. Data-data yang telah terkumpul kemudian direduksi atau dipilahpilah mana yang sesuai dan mendukung penelitian. Setelah data diolah kemudian disajikan dalam bentuk deskripsi, kemudian tahap terakhir disimpulkan.

\section{HASIL DAN PEMBAHASAN Nilai dan Etika dalam MMT}

Nilai-nilai manajemen mutu terpadu dari sebuah organisasi merupakan prinsi-prinsip yang menjadi dasar operasi dan pencarian organisasi tersebut 
dalam mencapai visi dan misinya. Nilai-nilai tersebut adalah mengutamakan para pelanggan, bekerja dengan standar integritas profesional tinggi, bekerja sebagi tim, memiliki komitmen terhadap peningkatan yang berkelanjutan, memberi kesempatan pada semua dan memberikan suatu pelayanan yang tertinggi (Blocher et al., 2011).

Etika bisnis adalah studi yang difokuskan tentang moral yang benar dan salah, dan berkonsentrasi pada standar moral sebagaimana diterapkan dalam kebijakan, institusi, dan perilaku bisnis. Di dalam etika bisnis keuntungan bukanlah satu-satunya tujuan organisasi, maka dari itu etika memiliki peranan yang sangat penting di dalam dunia bisnis (Velasquez, 2005). Etika adalah prinsip-prinsip moral dan nilai-nilai yang mengatur tindakan dan keputusan dari seorang individu atau kelompok (Story \& Hess, 2010).

Etika terkait dengan moral, sedangkan moral merujuk kepada nilai-nilai yang dipegang teguh masyarakat dan dianjurkan untuk ditaati. Etika dipakai sebagai sumber rujukan dalam merumuskan aturan, kesepakatan, dan hukum yang menjadi rambu-rambu dalam berperilaku sehari-hari. Perilaku beretika akan berada pada cakupan moral dan dalam konteks MMT meliputi khususnya kepercayaan (trust), tanggung jawab, dan integritas dimana semua ini merupakan nilai-nilai utama dari sistem manajemen mutu total/terpadu (Goetsch \& Davis, 1994).

Sutarto (2015) menguraikan terdapat enam topik yang relevan dengan etika dalam MMT yaitu pertama adalah defenisi dan rasional etika dalam MMT merupakan prinsip-prinsip moral yang termasuk ilmu tentang kebaikan dan sifat dari hak (the principles of morality, including the science of good and the nature of the right). Pedoman perilaku, yang diakui berkaitan dengan memperhatikan bagian utama dari kegiatan manusia (the rules of conduct, recognize in respect to a particular class of human actions). IImu watak manusia yang ideal, dan prinsip-prinsip moral sebagai individual (the science of human character in its ideal state, and moral principles as of an individual). Serta merupakan ilmu mengenai suatu kewajiban (the science of duty).

Kepercayaan (trust) dalam MMT merupakan resep utama dalam penerapan MMT. Tanpa adanya kepercayaan di antara individu termasuk antar manajer dan karyawan, maka penerapan MMT di suatu instansi sangat potensial gagal. Kepercayaan umumnya tumbuh bersamaan tumbuhnya perilaku yang beretika. Banyak elemen dalam total quality yang bergantung pada kepercayaan sebagai prasarat dalam berkontribusi terhadap peningkatan mutu, yaitu khususnya komunikasi, hubungan interpersonal, manajemen konflik, pemecahan masalah kerja tim, keterlibatan dan pemberdayaan karyawan, dan fokus pelanggan.

Aspek lain dari perilaku beretika dalam MMT adalah integritas. Integritas adalah karakter individu dan institusi yang merupakan kombinasi dari kejujuran (honesty) dan keteguhan hati (dependability). Ketika individu atau institusi mempunyai integritas maka perilaku beretika akan mengikutinya. Adalah penting bagi seorang manajer dalam institusi MMT untuk memahami walaupun kejujuran merupakan pondasi, integritas lebih dari sekedar kejujuran. Seseorang dengan integritas dapat diandalkan untuk mengerjakan sesuatu yang benar, dengan cara yang benar sampai tuntas selesai, tepat waktu, dan teguh memegang janji. 
Peran manajer dalam menegakan etika adalah bagian dari perilaku beretika yaitu menerima tanggung jawab. Dewasa ini ada kecenderungan karyawan pada umumnya lebih mengedepankan hak-hak mereka daripada memenuhi tanggung jawabnya. Mereka cenderung melempar tanggung jawab manakala terjadi kesalahan atau kegagalan. Dalam seting MMT semestinya tidak terjadi situasi seperti di atas. Karyawan bertanggung jawab atas tindakannya dan akuntabel atas kinerjanya. Menerima tanggung jawab adalah kredit bagi penggalangan kepercayaan, integritas, dan elemen lainnya dari etika yang sangat penting dalam lingkungan mutu total.

Peran organisasi dalam penerapan etika maksudnya adalah unsur birokrasi di atas manajer, misalnya direktur utama, pembina utama, penasehat perusahaan. Dalam bidang pendidikan, manajer dapat jadi kepala sekolah dan pembantunya sedang organisasi di atasnya adalah birokrat Dinas Pendidikan termasuk pengawas sekolah. Peran organisasi adalah mempromosikan perilaku beretika bagi seluruh karyawannya adalah sangat esensial. Manajer tidak akan mampu megakkan etika manakala tidak ada dukungan dari semua tingkatan birokrasi diatasnya dalam organisasi.

Perilaku beretika perlu dimengerti, dipahami, dihayati, dan diamalkan. Hal ini penting sejalan dengan tuntutan bisnis modern dan juga sejalan dengan ajaran MMT yang selalu berupaya meningkatkan mutu pelayanan sehingga dapat memenuhi bahkan melampaui harapan pelanggan/klien. Lebih spesifik dalam pengaturan (setting) MMT, perilaku beretika seperti kepercayaan, integritas, dan tanggung jawab adalah nilai-nilai yang menjadi dasar perilaku beretika dan perlu diinternalisasikan kepada setiap karyawan.

\section{Implementasi Nilai dan Etika di SD Muhammadiyah Sambisari}

SD Muhammadiyah Sambisari adalah satuan pendidikan swasta yang berada di bawah naungan yayasan Muhammadiyah. SD Muhammadiyah Sambisari didirikan dan mulai beroperasi pada tahun 1972. Berdiri diatas lahan waqaf seluas 800 meter persegi membuat lingkungan sekolah terhitung sempit. Sarana dan prasarana kurang memenuhi standar. Halaman atau tempat bermain siswa juga kurang memadai. Bahkan ruang kelas hanya berukuran $6 \times 7$ meter. Saat ini SD Muhamamdiyah Sambisari dipimpin oleh seorang sarjana Pendidikan Guru Sekolah Dasar bernama Ibu Sri Widi Astuti.

Dengan sarana dan prasarana yang seadanya, SD Muhammadiyah Sambisari mengalami tantangan besar dalam meningkatkan mutu. Karena sarana dan prasarana atau fasilitas yang memadai menjadi salah satu faktor penting dalam meningkatkan mutu dan mempertahankan kualitas sekolah. Disamping itu lingkungan yang kurang mendukung suksesnya pendidikan menjadi salah satu penghambat dalam peningkatan mutu. Misalnya orang tua atau wali murid yang umumnya adalah warga menengah kebawah yang memiliki perhatian kurang terhadap pendidikan anak karena sibuk bekerja/mencari nafkah.

Namun, dengan penerapan nilai-nilai dan etika oleh kepala sekolah selaku manajer atau pemimpin di dalam instansi, SD Muhammdiyah Sambisari mulai berkembang dan meningkat mutunya. Nilai-nilai etika yang diterapkan dalam SD Muhammadiyah Sambisari yang tertera dalam dokumen kurikulum adalah nilai religius, nasionalis, mandiri, integritas, tanggung jawab, dan gotong royong. 
Kemudian dalam rangka membangun kepercayaan nilai-nilai yang ditonjolkan terutama adalah integritas dan tanggung jawab. Semua nilai-nilai ini diteladankan kepala sekolah sebagai pemimpin kepada guru dan karyawan, kemudian guru memberi contoh kepada siswa di dalam maupun di luar kelas, menjadi semacam budaya sekolah.

Berbagai cara yang dilakukan SD Muhammadiyah Sambisari dalam menerapkan nilai-nilai etika adalah pertama merumuskan nilai-nilai dan etika yang harus dipatuhi oleh pendidik dan tenaga kependidikan dalam kurikulum dan tata tertib sekolah (kepercayaan, integritas, dan tanggung jawab). Kedua, mengintegrasikan seluruh nilai-nilai dan etika yang telah dirumuskan ke dalam pembelajaran dan kegiatan sehari-hari di sekolah di dalam maupun di luar kelas. Ketiga, membuat poster atau tulisan di lingungan sekolah misalnya di tangga, dinding dan berbagai tempat yang mudah dilihat oleh guru, siswa, dan orang tua tentang nilai-nilai yang harus dipatuhi oleh seluruh warga sekolah. Keempat, melakukan evaluasi setiap bulan terhadap penerapan nilai dan etika yang berlangsung. Kelima, memberikan keteladanan (terutama peran kepala sekolah)

Selama empat tahun menjabat sebagai kepala sekolah, Ibu Sri sangat tertib dalam menerapkan etika dan perilaku yang baik dalam kehidupan seharisehari di sekolah. Sebagai kepala sekolah dia berhasil membangun kepercayaan penuh baik di lingkungan internal maupun eksternal. Hal ini berdampak cukup baik hingga jumlah siswa terus meningkat setiap tahunnya. Dalam 3 tahun terakhir jumlah siswa mencapai standar maksimal yaitu 28 siswa perkelas atau bahkan lebih. Jumlah siswa yang banyak merupakan salah satu indikator keberhasilan dalam membangun kepercayaan di masyarakat.

Sebagai pemimpin, perannya cukup baik dalam berkomunikasi dengan guru maupun karyawan. Kepala sekolah menggunakan pendekatan yang ramah dan memperhatikan kepentingan semua pihak. Dalam menyelesaikan masalah atau konflik juga demikian. Sehingga hampir semua konflik yang terjadi dapat terselesaikan dengan baik. Dia memiliki integritas yang tinggi, dimana ia berhasil merubah paradigma dari yang didominasi oleh kontrak kerja legal formal ke era jabat tangan dan kepercayaan. Etika kepala sekolah ini sangat menginspirasi anggota, sehingga para karyawan bekerja dengan sukarela dan penuh pengabdian.

Kepala sekolah mengusahakan untuk selalu menciptakan suasana lingkungan kerja yang sangat etis. Beliau memberi contoh loyalitas yang tinggi terhadap pekerjaan, misalnya tidak pulang sebelum pekerjaan tuntas, selalu pulang setelah semua karyawan pulang. Hal ini membuat rasa tanggung jawab tertanam pada guru dan karyawan pula. Mereka memastikan para siswa pulang dengan aman, menunggu sampai dijemput orang tuanya atau mengantarkan kerumahnya jika perlu. Diantara guru dan karyawan tidak ada perselisihan yang berarti, semua anggota organisasi dapat bersosialisasi dengan baik dengan sesama. Kesadaran dan tanggung jawab ini tentu memiliki peran penting dalam mendukung proses perubahan sosial di tengah masyarakat. Lebih-lebih bila peran ini dilakukan secara konsisten akan menghasilkan pelayanan jasa yang sangat bermanfaat bagi lembaga pendidikan (Supriyanto \& Machfudz, 2011). Pendidikan dalam perspektif sosialnya, akan melahirkan insan-insan terpelajar yang memiliki peranan penting dalam proses perubahan sosial di dalam masyarakat. Disamping itu, perilaku siswa sangat dipengaruhi oleh keluarga dan 
juga pendidik. Nilai dan etika yang tunjukkan oleh kepala sekolah terutama akan menginspirasi guru dan karyawan sehingga mereka melakukan hal yang sama. Begitu juga dengan peserta didik. Mereka akan cenderung meniru perilaku guru mereka karena dianggap sebagai panutan. Dengan adanya nilai yang dianut dan etika yang baik yang dilakukan oleh pendidik secara otomatis akan membuat perilaku siswa menjadi lebih baik.

Dalam hubungannya dengan organisasi yang menaungi sekolah, kepala sekolah menjalin hubungan yang baik. Dia menyusun kembali komite sekolah yang sebelumnya tidak aktif. Komite sekolah terdiri dari anggota Pimpinan Cabang Muhammadiyah, yaitu yang berfungsi sebagai pembina atau penasehat bagi satuan pendidikan disamping pengawas dan dinas pendidikan. Sebab tanpa dukungan dari pihak atasan atau unsur birokrasi manajer tidak akan mampu menegakkan etika di lingkungan kerjanya (Sutarto, 2015).

Secara umum penerapan nilai-nilai dan etika di SD Muhammadiyah Sambisari sudah cukup baik. Imbasnya terhadap peningkatan mutu juga cukup signifikan. Penerapan nilai dan etika terbukti mampu meningkatkan kepercayaan dan kepuasan pelanggan, sehingga menepis kekurangan, memaksimalkan sarana dan fasilitas yang terbatas, dan mencapai tujuan dari pendidikan secara perlahan-lahan. Saat ini SD Muhammadiyah Sambisari terakreditasi A oleh Badan Akreditasi Nasional Sekolah/Madrasah (BAN-SM). Menunjukkan bahwa sekolah memiliki kualitas mutu yang baik.

\section{SIMPULAN}

Komite sekolah terdiri dari anggota Pimpinan Cabang Muhammadiyah, yaitu yang berfungsi sebagai pembina atau penasehat bagi satuan pendidikan disamping pengawas dan dinas pendidikan. Penerapan nilai-nilai dan etika di SD Muhammadiyah Sambisari sudah cukup baik. Imbasnya terhadap peningkatan mutu juga cukup signifikan. Penerapan nilai dan etika terbukti mampu meningkatkan kepercayaan dan kepuasan pelanggan, sehingga menepis kekurangan, memaksimalkan sarana dan fasilitas yang terbatas, dan mencapai tujuan dari pendidikan secara perlahan-lahan. Saat ini SD Muhammadiyah Sambisari terakreditasi A oleh Badan Akreditasi Nasional Sekolah/Madrasah (BAN-SM). Menunjukkan bahwa sekolah memiliki kualitas mutu yang baik.

Nilai-nilai manajemen mutu terpadu dari sebuah organisasi merupakan prinsip-prinsip yang menjadi dasar operasi dan pencarian organisasi tersebut dalam mencapai visi dan misinya. Perilaku beretika yang berada pada cakupan moral dan dalam konteks MMT meliputi khususnya kepercayaan (trust), tanggung jawab, dan integritas. Implementasi nilai-nilai dan etika di SD Muhammadiyah Sambisari dalam rangka meningkatkan mutu pendidikan cukup efektif. Sekolah yang memiliki sarana dan prasarana atau fasilitias yang minimal pun dapat membangun budaya mutu dan terus meningkatkan kualitasnya. Hal ini menunjukkan penerapan nilai dan etika menjadi faktor yang sangat penting dalam upaya peningkatan mutu.

\section{REFERENSI}

Ali, M. H. (2020). Penerapan Etika Bisnis Dan Strategi Manajemen Saat Pandemi Covid-19 Bagi Umkm. Eco-Entrepreneurship, 6(1), 34-42. https://journal.trunojoyo.ac.id/eco-entrepreneur/article/view/8834 
Blocher, E. J., Stout, D. E., \& Cokins, G. (2011). Cost Management: A Strategic Emphasis (Manajemen Biaya: Penekanan Strategis). Salemba Empat.

Creswell, J. W. (2014). Research Design: Pendekatan Kualitatif, Kuantitatif dan Mixed. Pustaka Pelajar.

Crosby, P. B. (1979). Quality is Free: The Art of Making Quality Certain. New American Library.

Goetsch, D. L., \& Davis, S. (1994). Introduction to Total Quality: Quality, Productivity, Competitiveness (Merrill's International Series in Engineering Technology) (E. Cliffs (ed.)).

Gustini, N., \& Mauly, Y. (2019). Implementasi Sistem Penjaminan Mutu Internal Dalam Meningkatkan Mutu Pendidikan Dasar. Jurnal Isema : Islamic Educational Management, 4(2), 229-244. https://doi.org/10.15575/isema.v4i2.5695

Hadi, A. (2018). Konsepsi Manajemen Mutu Dalam Pendidikan. Idaarah: Jurnal Manajemen Pendidikan, 2(2), 269.

https://doi.org/10.24252/idaarah.v2i2.5260

Hairiyah. (2015). Konsep Manajemen Mutu Terpadu Dalam Pendidikan. LITERASI (Jurnal IImu Pendidikan), 6(1), 99. https://doi.org/10.21927/literasi.2015.6(1).99-110

Priatna, T. (2018). Total Quality Manajemen Untuk Peningkatan Mutu Madrasah. Jurnal Isema : Islamic Educational Management, 3(1). https://doi.org/10.15575/isema.v3i1.3316

Sallis, E. (2002). Total Quality Manajemen in Edication - Third Edition. Kogan Page.

Saparina, R., Wahab, A. A., \& Mirfani, A. M. (2020). Implementasi Total Quality Manajemen (TQM) dalam Peningkatan Layanan Sekolah. Jurnal Administrasi Pendidikan, 27(1), 97-115. https://doi.org/10.17509/jap.v27i1.24405

Sapri, M., Kaka, A., \& Finch, E. (2009). Factors That Influence Student's Level of Satisfaction With Regards To Higher Educational Facilities Services. Malaysian Journal of Real Estate, 4(1), 34-51. https://www.researchgate.net/publication/242292080_Factors_That_Influen ce_Student's_Level_of_Satisfaction_With_Regards_To_Higher_Education al_Facilities_Services

Singh, H., \& Singh, B. P. (2012). Ethical Values and Business Ethics in Multinational Companiies in India in Context Globalization : An Empirical Study. International Proceedings of Economics Development and Research, 51(47), 222-230. https://doi.org/10.7763/IPEDR. 2012. V51. 47

Story, J., \& Hess, J. (2010). Etichal Brand Management Customer Relationship and Ethical Duties. Journal of Product \& Brand Management, 19(4), 240249. https://doi.org/10.1108/10610421011059568

Sukmadinata, N. S., Jami'at, A. N., \& Ahman. (2008). Pengendalian Mutu Pendidikan Sekolah Menengah (Konsep, Prinsip, dan Instrumen). Refika Aditama.

Supriyanto, A. S., \& Machfudz, M. (2011). Metodologi Riset Manajemen Sumber Daya Manusia. UIN Malang.

Sutarto, H. (2015). Manajemen Mutu Terpadu (MMT-TQM): Teori dan Penerapan di Lembaga Pendidikan. UNY Press. 
Sholawati

Velasquez, M. G. (2005). Etika Bisnis: Konsep dan Kasus. Andi. 